\title{
Accumulation of Dopamine in Mouse Pancreatic B-Cells Following Injection of L-DOPA. Localization to Secretory Granules and Inhibition of Insulin Secretion*
}

\author{
L. E. Ericson, R. Håkanson, and I. Lundquist \\ Department of Anatomy, University of Göteborg, Göteborg, and Department of Pharmacology, University of Lund, Lund, Sweden
}

\begin{abstract}
Summary. Accumulation and subcellular localization of dopamine (DA) in pancreatic B-cells and its effects on insulin secretion were investigated in mice following a single injection of L-3,4-dihydroxyphenylalanine (L-DOPA). Electron microscopic autoradiography showed that ${ }^{3} \mathrm{H}-\mathrm{DA}$ formed from administered ${ }^{3} \mathrm{H}$-DOPA was present over B-cells as well as over other types of islet cells. Pretreatment of the animals with a decarboxylase inhibitor greatly reduced the number of autoradiographic grains. In the B-cells the ${ }^{3} \mathrm{H}$-DA-grains were associated with the secretory granules. The location of the label may suggest an incorporation in the periphery of the $\beta$-granule, rather than in the dense core, supposed to contain insulin. Accumulation of DA in the B-cells following L-DOPA administration was found to inhibit partially the insulin secretory response to different insulin secretagogues (glucose, glibenclamide and L-isopropylnoradrenaline (L-IPNA) ). Treatment with monoamine oxidase inhibitor + L-DOPA induced an almost total suppression of L-IPNAstimulated insulin secretion, whereas glucose-induced insulin release was still only partially inhibited. Pretreatment with a decarboxylase inhibitor abolished the effects of L-DOPA. It is suggested that intracellularly accumulated DA in the B-cell exerts an inhibitory action on insulin releasing mechanisms induced by different secretagogues and that this action might involve interference with a calcium translocation process at the level of the secretory granule.
\end{abstract}

\footnotetext{
* This work was supported by the Swedish Medical Research Council (Project Nos. 14X-4286, 04P-4289 and 12X-537) and "Vera and Carl J. Michaelsens donationsfond". The skilful technical assistance of Mrs. Lena Kvist, Mr. Peter Okmark and Mrs. Gunnel Bokhede is gratefully acknowledged
}

Key words: B-cell, B-cell granules, DOPA, dopamine, electron microscopic autoradiography, glibenclamide, glucose, insulin secretion, isopropylnoradrenaline, mouse.

Several years ago, Falck and Hellman [4] showed that pancreatic islet cells of different mammals, such as the guinea pig, cat, dog and horse, contain monoamines demonstrable by their formaldehyde-induced fluorescence. These amines were identified as 5-hydroxytryptamine (5-HT) or dopamine (DA) $[1,2]$. Later an electron microscopic histochemical study suggested that 5-HT in the guinea pig B-cells was associated with the secretory granules [10] and quantitative electron microscopic autoradiography revealed that in mouse pancreatic B-cells, the labelled monoamine ${ }^{3} \mathrm{H}-5-\mathrm{HT}$, formed from the administered precursor ${ }^{3} \mathrm{H}-5$-hydroxytryptophan $(5-\mathrm{HTP})$, was largely confined to the B-cell granules [3]. Recent studies in mice and rabbits have shown that B-cell 5-HT, formed upon administration of 5-HTP, modifies insulin release both in vivo [16] and in vitro [11, $25,26]$. Neither DA nor 5-HT are normally found in the B-cells of the mouse, but the cells are equipped with mechanisms for uptake and decarboxylation of amine precursors and for amine storage and degradation $[2,3,5]$.

In previous investigations $[3,16]$ we examined the subcellular localization of 5-HT in the B-cells of the mouse after administration of L-5-HTP, and the effects of this treatment on insulin release. In the present study the subcellular distribution of another monoamine, DA, and its possible effects on insulin secretion were examined. 


\section{Materials and Methods}

\section{Animals}

Female mice of the NMRI strain (Laboratory Animal Breeding, Laven, Denmark), weighing $20-30 \mathrm{~g}$, were used. The animals were kept on a standard pellet diet (Astra-Ewos, Södertälje, Sweden) and tap water ad libitum before and throughout the experiments.

\section{Drugs and Chemicals}

L-3,4-dihydroxyphenylalanine (L-DOPA) was obtained from Fluka AG, Buchs, Switzerland. Glibenclamide was a generous gift from Boehringer Mannheim $\mathrm{GmbH}$, Germany; L-Isopropylnoradrenaline bitartrate (L-IPNA) from Hässle AB, Göteborg, Sweden; Pargyline hydrochloride, a monoamine oxidase inhibitor (MAOI) from Abbot Lab., North Chicago, Ill., USA; and Ro-4-4602, an inhibitor of the aromatic amino acid decarboxylase, as the hydrochloride from Hoffmann-La Roche Ltd., Basel, Switzerland. ${ }^{3} \mathrm{H}-\mathrm{L}$-DOPA (specific activity $28 \mathrm{Ci} / \mathrm{mmole}$ ) was obtained from Radiochemical Centre, Amersham, England, and DL-2- ${ }^{14} \mathrm{C}-\mathrm{DOPA}$ (specific activity $10 \mathrm{mCi}$ / mmole) from New England Nuclear Corp. Collagenase $(137 \mathrm{U} / \mathrm{mg})$ was obtained from Worthington Biochemical Corp., Freehold, USA. The insulin immunoassay kits were kindly provided by Novo Ltd., Copenhagen, Denmark. All other drugs and chemicals were obtained from British Drug Houses Ltd., Poole, England.

\section{Experimental}

L-DOPA (0.26 mmole/kg body weight), glucose $(8.33 \mathrm{mmole} / \mathrm{kg})$, glibenclamide $(0.5 \mu \mathrm{mole} / \mathrm{kg})$ and L-IPNA $(1.37 \mu$ mole $/ \mathrm{kg})$ were injected into a tail vein. Pargyline $(0.27 \mathrm{mmole} / \mathrm{kg})$ and Ro-4-4602 $(0.85 \mathrm{mmole} / \mathrm{kg})$ were administered intraperitoneally. The radioactive compounds were given intravenously in a tail vein. All drugs were administered in $0.9 \% \mathrm{NaCl}$ in a volume of $0.2 \mathrm{ml} / 20 \mathrm{~g}$ mouse. Blood sampling was performed by the orbital bleeding technique in the unanaesthetised mouse, as previously described [22]. Plasma immunoreactive insulin levels (peak levels of the first phase of the insulin secretory process) were recorded 2 min (glucose and glibenclamide) or $5.5 \mathrm{~min}$ (L-IPNA) following the injection of the secretagogues. Repeated experiments in this laboratory have shown that maximum concentration of immunoreactive insulin in mouse plasma following a rapid intravenous injection of these compounds is achieved after 2-2.5 min (glucose), 1.5-2.5 min (glibenclamide) and 5-6 min (L-IPNA). Blood glu- cose levels were determined enzymatically [18]. The concentrations of insulin in plasma were determined by the method of Heding [8] using ${ }^{125}$ I-labelled pig insulin and guinea pig anti-pig insulin. Pancreatic islets were isolated by collagenase treatment as previously described [12]. Student's t-test was employed for tests of significance.

\section{Electron Microscopic Autoradiography}

${ }^{3} \mathrm{H}$-L-DOPA $(0.75 \mathrm{mCi} /$ animal) was injected in a tail vein. Under ether anaesthesia the pancreatic glands were fixed by perfusion via the heart with glutaraldehyde $20 \mathrm{~min}, 1 \mathrm{~h}$ and $3 \mathrm{~h}$ after injection of the label. Two mice were injected with Ro-4-4602 $1 \mathrm{~h}$ prior to the administration of ${ }^{3} \mathrm{H}-\mathrm{L}-\mathrm{DOPA}$ and their pancreatic glands were fixed by perfusion $20 \mathrm{~min}$ after administration of the label. The perfusion solution consisted of $3 \%$ glutaraldehyde buffered with 0.075 $\mathrm{M}$ sodium cacodylate, $\mathrm{pH}$ 7.2.

After perfusion of $50 \mathrm{ml}$, pieces of the splenic part of the pancreas were further immersed for $1-3 \mathrm{~h}$ in a similar glutaraldehyde solution and, following repeated washings in buffer, postfixed in $1 \%$ osmium tetroxide. After dehydration in ethanol, the tissue was embedded in Epon. Islet tissue was identified in the light microscope in $1 \mu \mathrm{m}$ thick sections. Pale gold sections were cut on an LKB Ultrotome, picked up on Formvar coated copper grids and covered with a layer of carbon by vacuum evaporation. A monolayer of the emulsion, Ilford L4, was applied by means of a wire loop. After exposure for $6-8$ weeks the autoradiographs were developed in Kodak D-19B for $2 \mathrm{~min}$ and fixed in Kodak F-24 fixer for $2 \mathrm{~min}$.

For the analysis of the electron microscopic autoradiographs the principles for determining grain densities devised by Salpeter et al. [23] were employed. First the distribution of autoradiographic silver grains with distance from the outer edge of the B-cell granules was obtained. The location of a grain was considered as the centre of the smallest circle necessary to encompass it. A similar distribution was then obtained for placebo points which were punched on to the prints in the form of a regular lattice. By dividing the number of silver grains with the number of placebo points in the same unit distance a density distribution was obtained. This density distribution was normalized by dividing the values of distance by the HD value assumed for the autoradiographic preparation used and setting the grain density at the edge of the B-cell granule as 1. HD is the distance from a line source in an autoradiographic specimen within which half of the number of silver grains falls [23]. Experimental distributions normalized in distance units of $\mathrm{HD}$ can be compared with theoretical dis- 


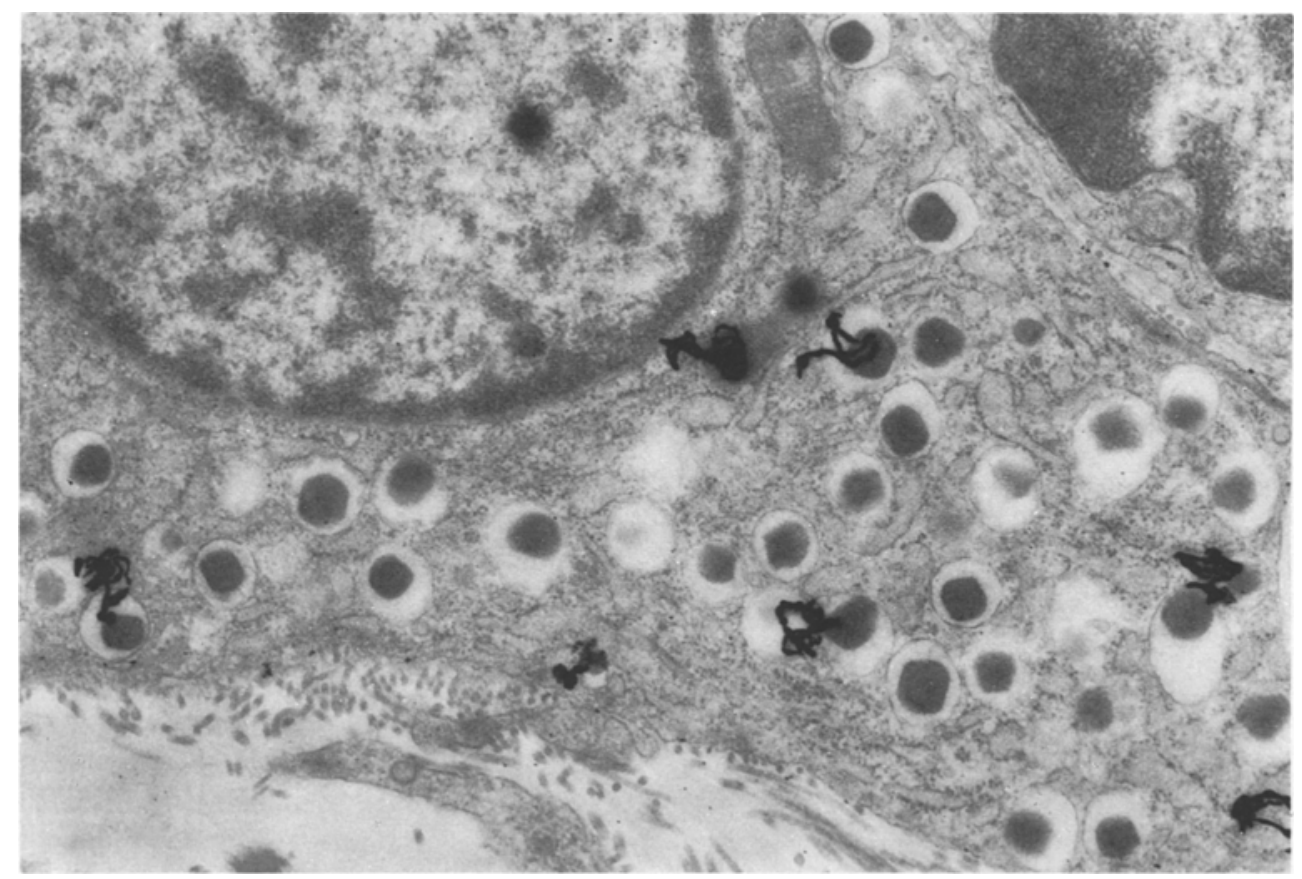

Fig. 1. Electron microscopic autoradiograph of a pancreatic B-cell from a mouse injected with ${ }^{3} \mathrm{H}-\mathrm{L}-\mathrm{DOPA} 20$ min prior to the fixation. The autoradiographic silver grains are located in close association with the B-cell granules. $\times 21,000$

tributions expected from radioactive sources differing in size and shape. Of particular interest in the present study was to compare the experimental grain distributions around $\beta$-granules with the theoretical distributions for a solid disc (label located in all parts within the membrane of the sectioned granule) and a hollow circle (label located in the periphery of the sectioned granule) as the $\beta$-granule has sufficient size, permitting discrimination between these alternatives [23]. In the present study HD was assumed to be $1650 \AA$ (cf 23). No correction for the change of the theoretical distribution curve caused by cross-fire from neighbouring labelled granules was made. Theoretical and practical estimations show that this change is small (J.-E. Andersson and L. E. Ericson, unpublished).

\section{Results}

\section{Electron Microscopic Autoradiography}

The number of autoradiographic grains over B-cells was about the same $20 \mathrm{~min}$ and $1 \mathrm{~h}$ after the injection of ${ }^{3} \mathrm{H}$-L-DOPA, while after $3 \mathrm{~h}$ an appreciably lower level of grains remained. In the animals pretreated with the DOPA decarboxylase inhibitor Ro-4-4602, few and randomly distributed grains were present over the B-cells.

The great majority of grains were located over the cytoplasm, mainly over areas containing granules, suggesting an association between the silver grains and the B-cell granules (Fig. 1). Autoradiographic grains were also present over other types of islet cells, but the precise cellular and intracellular distribution of this label was not further examined in the present study.

The experimental density distribution obtained showed a peak value inside the edge of the granule and a decline with increasing distance outwards from the edge. However, the baseline was not reached, but the curve levelled out at a density approximately $20 \%$ of the density at the edge of the granule. This indicated a certain level of "background activity" within the B-cell, which includes about $30 \%$ of the total number of grains.

Assuming that this background level of grains was randomly distributed within the cytoplasm, a new histogram was constructed by subtracting the background grains from the original histogram (Fig. 2). The curves superimposed on the histogram in Figure 2 are the predicted distribution of grains for a radioactive source acting as a hollow circle and a solid disc, respectively, both with a radius of $1.25 \mathrm{HD}$. (The average radius of the $\beta$-granules was $2000 \AA$ ). There is a good agreement between the experimental histogram and the theoretical distribution for a hollow circle. This indicates a location of label to the peripheral parts of the $\beta$-granules, either to the membrane or to the more or less electron-lucent space separating the membrane from the dense core. As- 


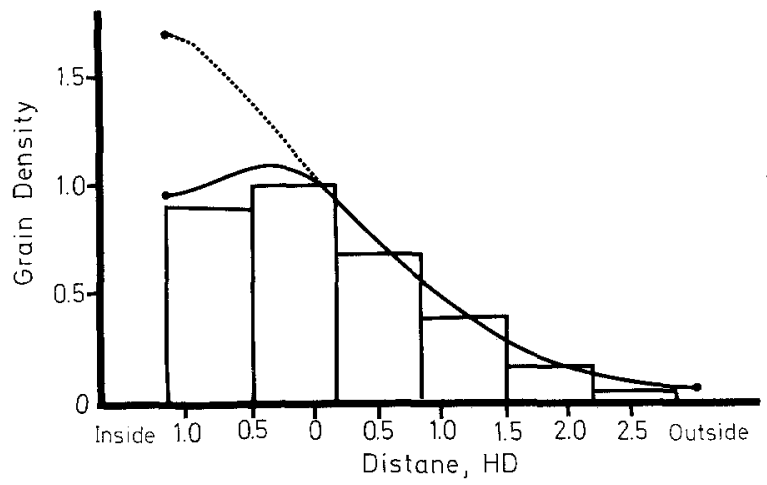

Fig. 2. A histogram showing the experimental grain density distribution relative to $\beta$-granules. The histogram was constructed from measurements of about 400 silver grains present in B-cells of mice injected with ${ }^{3} \mathrm{H}-\mathrm{L}-\mathrm{DOPA} 20 \mathrm{~min}$ prior to sacrifice. A background density amounting to about $20 \%$ of the maximal density over the granules was present in the B-cells. This background density was subtracted when constructing the histogram. $\mathrm{Chi}^{2}$-test revealed that the distribution of grains as shown in the histogram is highly non-random. The solid curve corresponds to the grain distribution expected for a labelled hollow circle equal in diameter to the $\beta$-granules. The broken curve corresponds to the expected grain distribution over a uniformly labelled disc equal in diameter to the $\beta$-granules

Table 1. Incorporation of DL-2- ${ }^{14} \mathrm{C}$-DOPA into islet protein (TCA-precipitate) in vivo $1 \mathrm{~h}$ and $2 \mathrm{~h}$, respectively, following the intravenous injection of the compound

\begin{tabular}{lrc}
\hline $\begin{array}{l}\text { Fraction } \\
\text { tested }\end{array}$ & $\begin{array}{l}\text { Amount of label } \\
\text { (Cpm }>\text { Blank im sample) }\end{array}$ & $\begin{array}{l}\text { Per cent } \\
\text { activity }\end{array}$ \\
\hline $\begin{array}{l}\text { Supernatant } 1 \mathrm{~h} \\
\text { TCA-precipitate 1 h }\end{array}$ & 1255 & 96.1 \\
Supernatant 2 h & 51 & 3.9 \\
TCA-precipitate 2 h & 21 & 95.6 \\
\hline
\end{tabular}

suming the latter possibility, the concentration of label inside the granules is more than 20 times higher than over other parts of the B-cell cytoplasm.

\section{Ability of Pancreatic B-Cells to Incorporate ${ }^{14} \mathrm{C}$ from Exogenous ${ }^{14} \mathrm{C}$-DOPA Into Protein}

In order to exclude the possibility that a significant proportion of the ${ }^{3} \mathrm{H}$-DOPA given was incorporated into islet cell proteins, the following experiment was performed. Eight mice were each injected with 0.03 $\mathrm{mCi}$ of DL-2- ${ }^{14} \mathrm{C}$-DOPA. After 1 and $2 \mathrm{~h}$, respectively, 4 mice were sacrificed and their pancreatic islets were isolated, washed extensively, and pooled [12]. The islets were then suspended in $0.1 \mathrm{ml}$ of Hanks solution and homogenized in a Potter-Elvehjem type microhomogenizer. The islet protein was precipitated by the addition of an equal volume of ice-cold $10 \%$ TCA (trichloroacetic acid). The supernatants and the
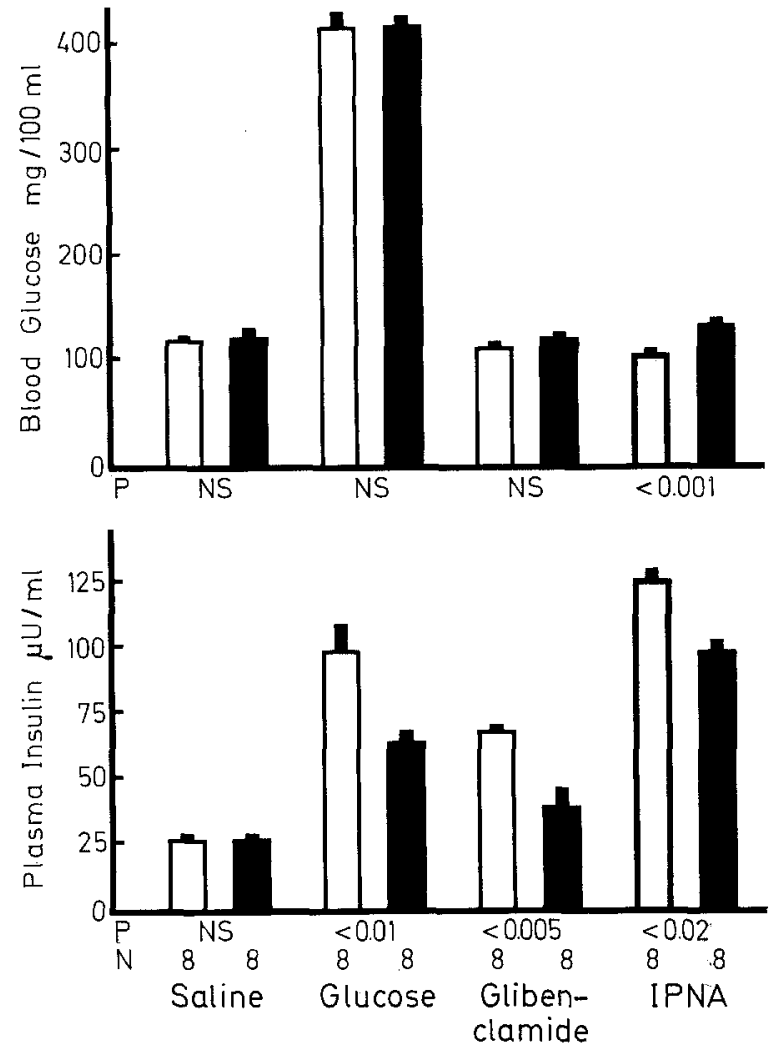

Fig. 3. Blood glucose levels and plasma immunoreactive insulin levels after intravenous injection of saline, glucose $(8.33 \mathrm{mmol} / \mathrm{kg})$, glibenclamide $(0.5 \mu \mathrm{mol} / \mathrm{kg})$, and L-IPNA $(1.37 \mu \mathrm{mol} / \mathrm{kg})$, respectively. Pretreatment with saline (white columns) or L-DOPA $(0.26$ $\mathrm{mmol} / \mathrm{kg}$ ) (black columns), was given one hour prior to the experiment. Vertical bars indicate standard error of the mean. $\mathrm{P}=$ probability level of random difference. $\mathrm{NS}=$ not significant. $\mathrm{N}=$ number of animals in each group

precipitates were then counted in a Packard Tri-Carb Liquid Spectrometer. The results are presented in Table 1 . The amount of radioactivity that may have been incorporated into protein did not exceed $4 \%$ of total activity after one hour and $4.5 \%$ after two hours (Table 1). This supports the view that the radioactivity observed in the B-cells reflects the presence of DA.

\section{Effect of an Intravenous Injection of $L-D O P A$ on Basal and Stimulated Insulin Release}

This experiment (Fig. 3) was designed to elucidate the influence of pretreatment with L-DOPA on plasma immunoreactive insulin and blood glucose levels after injection of saline $(0.9 \% \mathrm{NaCl})$ and the different insulin secretagogues glucose, glibenclamide and L-IPNA, respectively. Glucose, the potent sulphonylurea derivative, glibenclamide and the $\beta$-adrenergic agonist L-IPNA have previously been shown to be effi- 


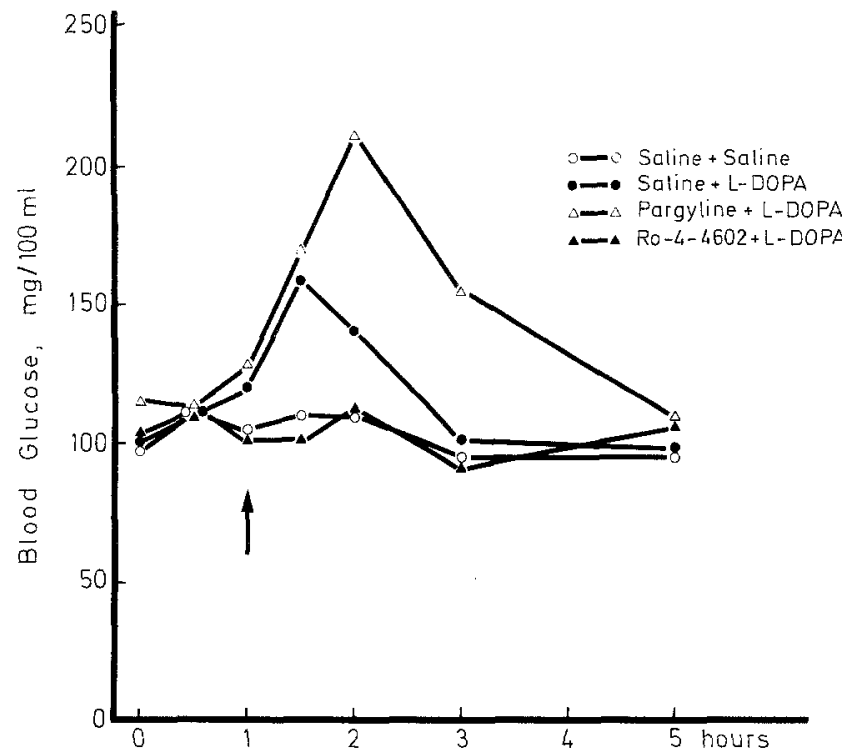

Fig. 4. Changes in the level of blood glucose in mice following the intravenous injection of saline or L-DOPA, $0.26 \mathrm{mmol} / \mathrm{kg}$, (marked by an arrow). Saline, pargyline $(0.27 \mathrm{mmol} / \mathrm{kg})$ or Ro-4-4602 $(0.85 \mathrm{mmol} / \mathrm{kg})$ was given intraperitoneally at the time 0 . Each group consisted of 5-7 animals. Abscissa: time in hours. Ordinate: blood glucose level, $\mathrm{mg} / 100 \mathrm{ml}$

cient insulin releasers in mice [16]. L-DOPA $(0.26$ $\mathrm{mmol} / \mathrm{kg}$ body weight) was given one hour prior to the injection of insulin secretagogue, because, according to the autoradiographic findings, the DA stores associated with insulin secretory granules in the B-cells were maximally loaded at this time. Figure 3 shows that L-DOPA had no effect on basal plasma insulin or blood glucose levels. However, in animals pretreated with L-DOPA a moderate decrease in the peak levels of plasma insulin was noted following all three insulin secretagogues; glucose $(\mathrm{p}<0.01)$, glibenclamide $(\mathrm{p}<$ $0.005)$ and L-IPNA $(\mathrm{p}<0.02)$. The blood glucose levels of DOPA-treated and control mice were similar in all groups except that a small but significant rise was recorded in the L-DOPA + L-IPNA-treated group compared with the group treated with L-IPNA alone.

\section{L-DOPA-Induced Changes in Blood Glucose Concentration, Following Pretreatment with Saline, a Monoamine Oxidase Inhibitor or a Decarboxylase Inhibitor}

Changes in the blood glucose during the hour that elapsed from the intravenous injection of L-DOPA to the time of injection of insulin secretagogue, might have influenced the magnitude of the insulin response to the secretagogue. To follow the blood glucose pattern during this time interval (Fig. 4), groups of mice (5- 7 animals per group) were injected intraperitoneally with either saline, the monoamine oxidase in-

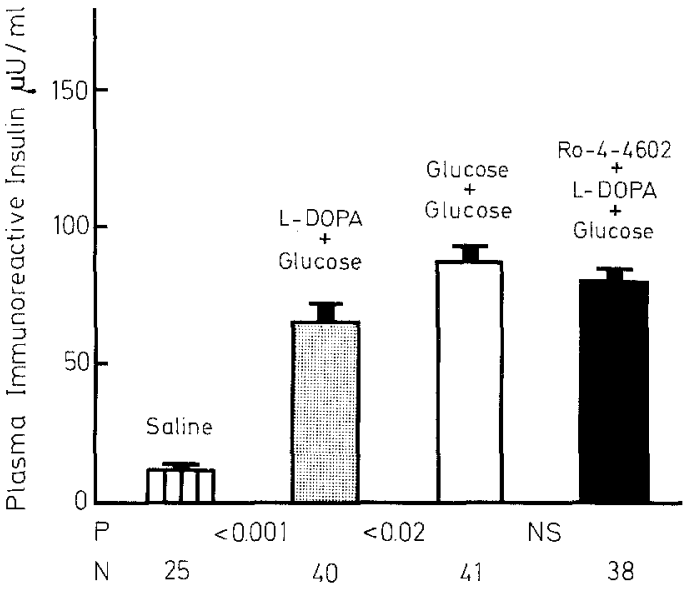

Fig. 5. Plasma immunoreactive insulin levels after intravenous injection of saline or glucose $(8.33 \mathrm{mmol} / \mathrm{kg})$, respectively. Pretreatment with saline, L-DOPA $(0.26 \mathrm{mmol} / \mathrm{kg})$ or glucose $(4.17$ $\mathrm{mmol} / \mathrm{kg}$ intraperitoneally) was given one hour prior to the experiment. A further pretreatment with Ro-4-4602 $(0.85 \mathrm{mmol} / \mathrm{kg})$ in one of the L-DOPA groups was given at $-2 \mathrm{~h}$. Vertical bars indicate standard error of the mean. $P=$ probability level of random difference. $\mathrm{NS}=$ not significant. $\mathrm{N}=$ Number of animals in each group

hibitor pargylline $(0.27 \mathrm{mmol} / \mathrm{kg})$, or the decarboxylase inhibitor Ro-4-4602 $(0.85 \mathrm{mmol} / \mathrm{kg})$. Blood samples were taken at 0,30 and $60 \mathrm{~min}$. Immediately after taking the blood sample at $60 \mathrm{~min}$, the animals were injected intravenously with either saline or LDOPA $(0.26 \mathrm{mmol} / \mathrm{kg})$ and the blood glucose response was recorded as illustrated in Figure 4. The injection of L-DOPA induced a rapid hyperglycaemic response, which returned to normal about $1-1.5 \mathrm{~h}$ following the injection. Pargyline markedly enhanced the hyperglycaemic response to L-DOPA, while Ro-4-4602 virtually abolished it.

\section{Effect of Pretreatment with Ro-4-4602 or Pargyline on the Inhibitory Action of L-DOPA on Glucose-Induced Insulin Release}

A series of experiments was designed to elucidate the effects of pharmacological blockade or enhancement of amine formation following exogenous L-DOPA on glucose-induced insulin release. The first experiment (Fig. 5) was designed to see whether the partial inhibition exerted by L-DOPA pretreatment on glucose-induced insulin release (Fig. 3) was still apparent when the preceding hyperglycaemic effect of L-DOPA (Fig. 4) was mimicked by giving glucose to the control group. In the same experiment another group of mice was pretreated with the decarboxylase inhibitor Ro-4-4602. It appears from Figure 5 that glucose-induced insulin release is still slightly inhibited by the 


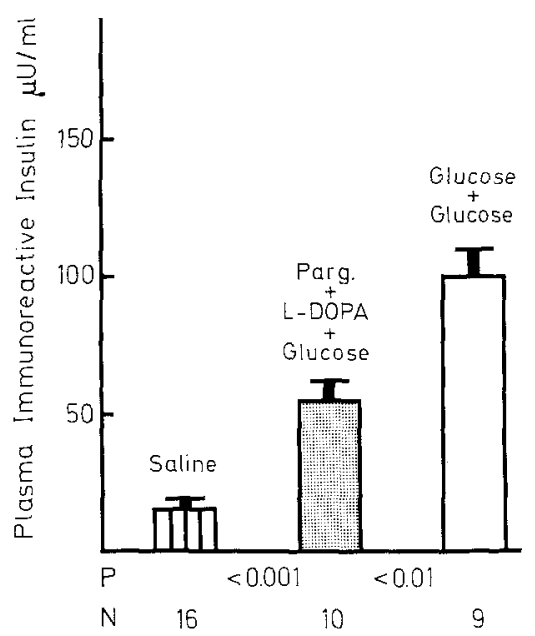

Fig. 6. Plasma immunoreactive insulin levels after intravenous injection of saline or glucose $(8.33 \mathrm{mmol} / \mathrm{kg})$, respectively. Pretreatment with saline, L-DOPA $(0.26 \mathrm{mmol} / \mathrm{kg})$ or glucose $(4.17$ $\mathrm{mmol} / \mathrm{kg}$ ) intraperitoneally, was given one hour prior to the experiment. A further pretreatment with pargyline $(0.27 \mathrm{mmol} / \mathrm{kg})$ in the L-DOPA group was given by three intraperitoneal injections at $25,-18$ and $-2 \mathrm{~h}$. Vertical bars indicate standard errors of the mean. $\mathrm{P}=$ probability level of random difference. $\mathrm{NS} \doteq$ not significant. $\mathrm{N}=$ number of animals in each group

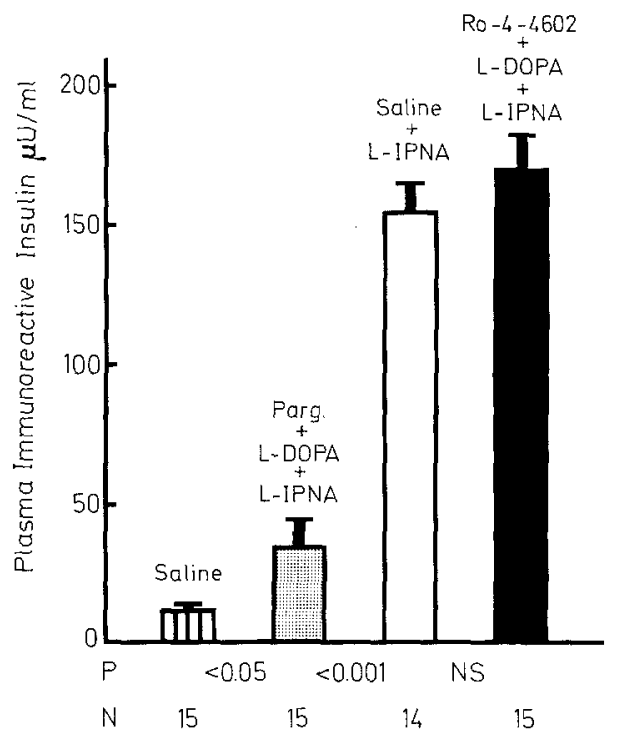

Fig. 7. Plasma immunoreactive insulin levels after intravenous injection of saline or L-IPNA $(1.37 \mu \mathrm{mol} / \mathrm{kg})$, respectively. Pretreatment with saline or L-DOPA $(0.26 \mathrm{mmol} / \mathrm{kg})$ was given one hour prior to the experiment, and pretreatment with Ro 4-4602 $(0.85$ $\mathrm{mmol} / \mathrm{kg}$ ) was given at $-2 \mathrm{~h}$. A further pretreatment with pargyline $(0.27 \mathrm{mmol} / \mathrm{kg})$ in one group was given by three intraperitoneal injections at $-25,-18$, and $-2 \mathrm{~h}$. Vertical bars indicate standard errors of the mean. $\mathrm{P}=$ probability level of random differences. $\mathrm{NS}=$ not significant. $\mathrm{N}=$ number of animals in each group one hour L-DOPA treatment (stippled column) when compared with the glucose injected controls (white column), which were given an intraperitoneal injection of glucose instead of saline at $-1 \mathrm{~h}$. Pretreatment with Ro-4-4602 (black column) one hour before LDOPA injection abolished the inhibitory effect of L-DOPA. Blood glucose levels in the three glucoseinjected groups were of the same order of magnitude as follows (means \pm SEM): L-DOPA + glucose 412 $\pm 14 \mathrm{mg} / 100 \mathrm{ml}$, glucose + glucose $410 \pm 10 \mathrm{mg} / 100$ $\mathrm{ml}$ and Ro-4-4602 + L-DOPA + glucose $439 \pm 11$ $\mathrm{mg} / 100 \mathrm{ml}$. Blood glucose level in the saline-treated group was $109 \pm 6 \mathrm{mg} / 100 \mathrm{ml}$. Another experiment (Fig. 6) was carried out to see whether pretreatment with the monoamine oxidase inhibitor, pargyline, accentuated the suppressing effect of L-DOPA on glucose-induced insulin release. Figure 6 shows that glucose-stimulated insulin secretion was partially, but far from totally, suppressed by the combined treatment of pargyline and L-DOPA (stippled column) when compared with the glucose-injected controls (white column), pretreated with $4.17 \mathrm{mmol} / \mathrm{kg}$ glucose intraperitoneally, and the animals injected with saline only (striped column). As before, there was no difference between blood glucose levels in the two glucose-injected groups.

\section{Effect of Pretreatment with Ro-4-4602 or Pargyline on the Inhibitory Action of L-DOPA on L-IPNA-Induced Insulin Release}

In this experiment (Fig. 7) groups of mice were pretreated with either pargyline + L-DOPA (stippled column), saline (white column), or Ro-4-4602 + LDOPA (black column) and then injected with L-IPNA. Saline controls were included (striped column). It appears from Figure 7 that L-IPNA-induced insulin release was almost totally inhibited by pargyline + L-DOPA, whereas it was unaffected by pretreatment with Ro-4-4602 + L-DOPA. There was no significant difference in the blood glucose levels between the different groups.

\section{Discussion}

Studies with light microscopic autoradiography have demonstrated the uptake of DOPA and 5-HTP in the pancreatic islets of the mouse and rabbit $[5,21,25]$. By decarboxylation of these amino acids the corresponding amines are formed and stored in the cytoplasm [6]. Studies at the light microscopic level, however, furnish little information as to the precise subcellular localization of the amines formed. Such informa- 
tion should be of considerable importance for the understanding of the significance of monoamines in islet cells. In a previous study [3] we demonstrated by electron microscopic autoradiography that labelled 5-HT, formed from injected ${ }^{3} \mathrm{H}-5-\mathrm{HTP}$, was largely confined to the specific granules of the B-cells.

In the present study a similar autoradiographic technique was applied to pancreatic islets following ${ }^{3} \mathrm{H}-\mathrm{L}-\mathrm{DOPA}$. As previously discussed [3] this technique mainly reveals the presence of the monoamine rather than the precursor amino acid, which is here further demonstrated by the absence of autoradiographic grains following pretreatment with an inhibitor of the decarboxylating enzyme. The incorporation of label into proteins seems not to be significant, as shown by the experiments with isolated islets.

Interest was focussed on the intragranular distribution of the labelled monoamine. The experimental grain density distribution around B-cell granules was compatible with the theoretical distribution for a radioactive source acting as a hollow circle [23]. This suggests location of label towards the periphery of the $\beta$-granules rather than at the central dense core containing insulin [19]. About $1 / 3$ of the radiographic silver grains encountered over the B-cell cytoplasm were not related to granules. At present it is impossible to decide if these belonged there or represent label artefactually displaced from the granules during the preparation procedure.

Assuming binding of label to material present within the $\beta$-granules, but outside the dense core, the concentration of intragranular label (in all probability representing DA) was about 20 times higher than the concentration of extragranular label. As results in the present study are compatible with the view [7] that the hyperglycaemic effect of L-DOPA is due to DA, the high concentration of $\mathrm{DA}$ in the $\beta$-granules suggests that at least a part of its hyperglycaemic effects might be exerted on insulin storage or releasing mechanisms. The absence of specific labelling of the dense core, thought to represent stored insulin [19], makes it unlikely that the amine is complexed with insulin. Instead, the present morphological and functional data lend more support to the idea that intracellular DA concentrated in the $\beta$-granules affects the process of insulin release $[7,13,14]$ in a way similar to that suggested for 5-HT $[13,14,16]$.

It was recently demonstrated by analytical electron microscopy $[9,24]$ that stimulation of insulin secretion by glucose brought about an apparent shift of calcium from the endoplasmic reticulum and the mitochondria into the haloes of the secretory granules of the B-cells. The similar topographical distribution of DA suggested by the present observations raises the possibility of interference with this calcium trans- location process. Neither 5-HT nor DA has been shown to be present in the B-cells of the mouse. It cannot be excluded, however, that the effects described mimic those of monoamines in B-cells of those species where they are present in concentrations readily detected and identified by available histochemical techniques $[2,20]$.

We found that accumulation of DA in the B-cells partially suppressed the insulin response to three chemically very different secretagogues (Fig. 3). These secretagogues were also tested in a previous study concerning the effect of an exogenously induced accumulation of 5-HT in mouse B-cells on insulin secretion [16]. In that study, the greatest difference in 5-HT effect was found between glucose and L-IPNA. Glucose-induced insulin release was not affected at all, even after combined treatment with the monoamine oxidase inhibitor, pargyline + L-5-HTP, whereas L-IPNA-induced insulin release was found to be totally suppressed. The present results show that this pattern is also present after pretreatment with pargyline + L-DOPA. L-IPNA-induced insulin release was again almost totally suppressed (Fig. 7), whereas glucose-induced insulin release was only partially inhibited (Fig. 6). Although there is a difference between DA and 5-HT with respect to the effect on glucose-induced insulin release, the influence exerted by the two monoamines on the effects of the different secretagogues seems to be very similar. The mechanism of action of the granule-located amine on the insulin secretory processes remains to be elucidated. It has previously been suggested that the partial inhibition of sulphonylurea-induced insulin release, which is brought about by DA and 5-HT, might be due to an interaction with the glycogenolytic hydrolase, acid amyloglucosidase in the B-cell $[13,14]$. This effect, however, seems to be different from the profound inhibitory action on insulin secretion stimulated by L-IPNA, since L-IPNA-induced insulin release apparently is independent of acid amyloglucosidase activity $[15,17]$. An alternative and/or supplementary explanation might be an interaction between the amine and calcium as discussed above. Since calcium is an essential requirement for the release of insulin, it is possible that the intragranular amine might play a role in preventing translocated calcium from access to an intragranular site. In this way amines may influence the chain of events leading to insulin secretion.

\section{References}

1. Cegrell, L.: Monoamine-containing cells in the fetal and newborn guinea-pig pancreas. Life Sci. 6, 1647-1652 (1967)

2. Cegrell, L.: The occurrence of biogenic monoamines in the mammalian endocrine pancreas. Acta Physiol. Scand. Supp. 314 (1968) 
3. Ekholm, R., Ericson, L. E., Lundquist, I.: Monoamines in the pancreatic islets of the mouse. Subcellular localization of 5hydroxytryptamine by electron microscopic autoradiography. Diabetologia 7, 339-348 (1971)

4. Falck, B., Hellman, B.: Evidence for the presence of biogenic amines in pancreatic islets. Experientia (Basel) 19, 139-140 (1963)

5. Gershon, M.D., Ross, L. L.: Location of sites of 5-hydroxytryptamine storage and metabolism by radioautography. J. Physiol. (Lond.) 186, $477-492$ (1966)

6. Gylfe, E., Hellman, B., Sehlin, J.-O., Täljedal, I.-B.: Amino acid conversion into 5 -hydroxytryptamine in pancreatic $\beta$-cells. Endocrinology 93, 932-937 (1973)

7. Håkanson, R., Lundquist, I., Rerup, C.: On the hyperglycaemic effect of DOPA and dopamine. Eur. J. Pharmacol. 1, 114-119 (1967)

8. Heding, L.: A simplified insulin radioimmunoassay method. In: Labelled proteins in tracer studies (ed. L. Donato), pp. 345-350. Brussels: Euratom 1966

9. Herman, L., Sato, T., Hales, C.N.: The electron microscopic localization of cations to pancreatic islets of Langerhans and their possible role in insulin secretion. J. Ultrastruct. Res. 42, 298-311 (1973)

10. Jaim-Echeverry, G., Zieher, L.M.: Electron microscopic cytochemistry of 5-hydroxytryptamine in the beta cells of guinea pig endocrine pancreas. Endocrinology 83, 917-923 (1968)

11. Lernmark, $\AA$.: The significance of 5-hydroxytryptamine for insulin secretion in the mouse. Horm. Metab. Res. 3, 305-309 (1971)

12. Lundquist, I.: Method for determination of acid amyloglucosidase in isolated islets of the pancreas. Enzyme 12, 647-657 (1971)

13. Lundquist, I.: Acid amyloglucosidase and carbohydrate regulation. III. The induction of sulphonylurea-stimulated insulin release and its dependence on intracellular monoamines. Horm. Metab. Res. 4, 341-348 (1972)

14. Lundquist, I.: Insulin secretion. Its regulation by monoamines and acid amyloglucosidase. Acta Physiol. Scand. 372, (Suppl.) $1-47$ (1971)

15. Lundquist, I.: Significance of acid amyloglucosidase in sulphonylurea-induced insulin release. Diabetologia 10, 717-724 (1974)

16. Lundquist, I., Ekholm, R., Ericson, L.E.: Monoamines in the pancreatic islets of the mouse. 5-hydroxytryptamine as an in- tracellular modifier of insulin secretion and the hypoglycaemic action of monoamine oxidase inhibitors. Diabetologia 7, 414-422 (1971)

17. Lundquist, I., Lövdahl, R.: Islet amyloglucosidase and sulphonylurea-stimulated insulin release in three different strains of mice. Horm. Metab. Res. 7, 6-9 (1975)

18. Marks, V.: An improved glucose oxidase method for determining blood, C.S.F. and urine glucose levels. Clin. Chim. Acta 4, 395- 401 (1959)

19. Misugi, K., Howell, S. L., Greider, M. H., Lacy, P. E., Sorenson, G.D.: The pancreatic beta cell. Demonstration with peroxidase-labeled antibody technique. Arch. Pathol. 89, 97-102 (1970)

20. Owman, C., Håkanson, R., Sundler, F.: Occurrence and function of amines in endocrine cells producing polypeptide hormones. Fed. Proc. 32, 1785-1791 (1973)

21. Ritzén, M., Hammarström, L., Ullberg, S.: Autoradiographic distribution of 5-hydroxytryptamine and 5-hydroxytryptophan in the mouse. Biochem. Pharmacol. 14, 313-321 (1965).

22. Rerup, C., Lundquist, I.: Blood glucose level in mice. I. Evaluation of a new technique of multiple serial sampling. Acta Endocrinol. (Kbh.) 52, 357-367 (1966)

23. Salpeter, M.M., Bachmann, L., Salpeter, E.E.: Resolution in electron microscope radioautography. J. Cell Biol. 41, 1-20 (1969)

24. Schäfer, H. J., Klöppel, G.: The significance of calcium in insulin secretion. Ultrastructural studies on identification and localization of calcium in activated and inactivated B-cells of mice. Virchows Arch. (Pathol. Anat.) 362, 231 - 245 (1974)

25. Tjälve, H.: Catechol- and indolamines in some endocrine cell systems. Acta Physiol. Scand. Suppl. 360 (1971)

26. Wilson, J.P., Downs, Jr., R.W., Feldman, J.M., Lebowitz, H. E.: Beta cell monoamines: further evidence for their role in modulating insulin secretion. Amer. J. Physiol. 227, 305-312 (1974)

Received: August 25, 1976, and in revised form: December 10, 1976

Dr. I. Lundquist

Dept. of Pharmacology

Sölvegatan 10

S-22362 Lund

Sweden 